\title{
Review: Gernot Böhme, 2017, The Aesthetics of Atmospheres. Edited by Jean-Paul Thibaud. London, Routledge
}

\section{Mikkel Bille}

\section{(2) OpenEdition}

1 Journals

\section{Electronic version}

URL: https://journals.openedition.org/ambiances/1065

DOI: 10.4000/ambiances. 1065

ISSN: 2266-839X

\section{Publisher:}

Direction Générale des Patrimoines - DAPA - MCC, UMR 1563 - Ambiances Architectures Urbanités $(\mathrm{AAU})$

\section{Electronic reference}

Mikkel Bille, "Review: Gernot Böhme, 2017, The Aesthetics of Atmospheres. Edited by Jean-Paul

Thibaud. London, Routledge", Ambiances [Online], Reports, Online since 20 February 2018, connection on 21 September 2021. URL: http://journals.openedition.org/ambiances/1065 ; DOI: https://doi.org/ 10.4000/ambiances.1065

This text was automatically generated on 21 September 2021.

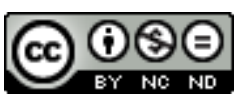

Ambiances is licensed under a Creative Commons Attribution-NonCommercial-NoDerivatives 4.0 International License. 


\title{
Review: Gernot Böhme, 2017, The Aesthetics of Atmospheres. Edited by Jean-Paul Thibaud. London, Routledge
}

\author{
Mikkel Bille
}

\section{REFERENCES}

Gernot Böhme. 2017. The Aesthetics of Atmospheres. Edited by Jean-Paul Thibaud. London: Routledge.

1 Finally! A collection of Gernot Böhme's work on atmospheres and aesthetics translated into English. I say "finally" because discussions on atmospheres in Anglophone academic circles over the last decade have indeed been a mixed experience. On the one hand, the focus on atmospheres and the closely related so-called "affective turn" has been extremely fruitful for understanding affective and emotional aspects of human lives as they unfold through space. Here, Böhme's notion of atmosphere as the copresence of subject and object has been a common reference point for thoughtprovoking analyses and theoretical developments. On the other hand, it has been a constant point of irritation to me that Böhme's argument in the Anglophone literature is more or less solely based on the 1993 and 1998 English articles from Thesis Eleven and Daidalos, when a much more nuanced picture is painted in the many books and articles in German that he has produced on the topic. The Aesthetics of Atmospheres partly mends that gap, and hence I sincerely welcome the book. It offers theoretical depth to the ongoing discussions on atmospheres and aesthetics.

2 As editor Jean-Paul Thibaud rightly notes in the introduction, the book bears witness to the work and invention that has been required to make the notion of atmosphere so successful and accepted. From the central arguments of Böhme's philosophy on 
atmosphere as that through which the world appears, to insightful discussion on architecture, nature, sound and light, the book will inspire the reader to think differently. Geography in particular, and social science more broadly, have seen the rise of a notion of "affective atmospheres" (as if there are non-affective atmospheres), combining thinking from Deleuze/Massumi/Thrift-inspired literature on affect and Böhme's work on atmosphere. Readers engaged in the so-called "affective turn" should be warned, however, that there is very little explicit discussion of similarities and overlaps between the concepts of affect and atmosphere in this collection. Rather, it is a phenomenologically anchored argument about aesthetics, atmospheres, and much more. And as such, it offers a nuanced introduction to the scope of Böhme's work and understanding of atmospheres.

3 One of the things I particularly take from the collection is an awareness of Böhme's continued insistence on the political potential - for better or worse - of atmospheres and aesthetics. By highlighting the possibility of approaching atmospheres from both a consumption and a production side, Böhme indicates throughout the collection how atmospheres may seem the most commonplace and work as a premise for engaging with the world, but there is a production aspect with political potential when atmospheres are staged. That is, atmospheres are active in shaping the world, thus showing the two sides of atmospheres where the environment 'radiates' a quality of mood and the person participates in this mood with his/her own sensitivity.

The section on light was of particular interest to me, as it was also included as a new topic in the second edition of his 1995 book, Atmosphäre, in 2013. In the two final chapters, Böhme takes up the otherwise widespread notion that we do not see light, but see in it. The common understanding is that we see light hitting dust particles, for instance, but not light itself. Böhme disagrees. As he notes, "we do not actually see the luminous dust particles as dust particles; we simply know that that is what they are. We see points of light." (p. 195). He notes that light is a precondition for seeing at all, whereas darkness is a precondition for seeing something. Yet to prove his point, he investigates what it means to see light in the chapter Seeing Light. In my opinion, he offers a fruitful way of understanding the relationship between light, space, surface and vision by promoting the notion of lightness as different from light, in the same way as dark and darkness are distinct. Lightness, in this sense, highlights space, not as surfaces illuminated by beams of light, but as a quality of the space that surrounds us. While that in itself is an interesting argument, he is also careful not simply to distinguish darkness and lightness, but to emphasize that brightness is a degree of lightness, and thus makes the reader aware of how glow, brightness, colour, luminance etc. are part of lightness as a basic experience. Unfortunately, the following chapter, Phenomenology of light, does not carry on this emphasis on lightness, but simply promotes brightness as the basic experience of light.

5 The diversity not only in terms of topics - from atmospheres to aesthetics, nature, architecture, sound, music, and light - but also in writing style shows the breadth of Böhme's intellectual project. The collection takes the reader from rigid philosophical discussions on Kant and Aristotle, the logical argumentation of the inadequacy of a scientific definition of light, to normative statements that simple geometrical forms bore us (p. 61), or how 'the contributions of artists engaged in the ecological discourse are unfortunately often at the level of an average newspaper reader and pub philosopher' (p. 119). One can see the reason for the editor's choice of chapters, and all 
chapters highlight topics that offer food for thought. It happens when we learn about "lightness", "the space of bodily presence" as an alternative to geometrical or scientific approaches to space, or when we shift the focus away from the objective functions and properties of things towards their dramatic value as ecstatic. Such intellectual reversals are central to a phenomenological approach and in the hands of Böhme we are offered new insights.

Since any proper book review also must contain criticism, this is also where my main concern lies with the collection of articles I otherwise enjoyed reading or re-reading in English translation. In my view, it will be a book where individual chapters will be picked out by scholars or used for teaching, such as The atmosphere of a city or Seeing Light, which I particularly enjoyed. But it is not a book that one reads from cover to cover. Most chapters are to the point, presented in clear and comprehensible language, even for non-philosophers, but they are also quite brief and jump forward quickly in terms of argument. Others, such as the interesting article on Kant's aesthetics, take quite a lot more effort to read. It is not a criticism of the content of the collection, as such. I am simply pointing out that the effort it takes to read the different chapters varies quite considerably. Furthermore, and this is perhaps inevitable when compiling a collection such as this, there is quite a lot of repetition of examples, disrupting the pleasure of reading it in full. Particularly towards the end of the book, the articles have very large sections that one has already read in the previous chapters. This goes for the critique of Arthur Zanjonc, or the examples of a Bach fugue, John Cage or Turrell. While the selection of articles thus on the one hand shows the breadth, we also end up with repeated content, or with the same logic not being followed, as in the case of light and lightness / brightness. And this is a shame for a book that will otherwise no doubt stand to nuance the existing discussion in the Anglophone world of atmospheres and aesthetics.

7 This minor criticism aside, the collection is welcomed for further introducing Böhme's fundamental thinking and the breadth of his work to an English-speaking audience. The insights, critiques and new ideas and terminology it offers will no doubt inspire our thinking in the future.

\section{AUTHOR}

\section{MIKKEL BILLE}

Mikkel Bille, Associate Professor, Roskilde University. 